\title{
The water column as an attenuating factor of the UVR effects on bacteria from a coastal Antarctic marine environment
}

\author{
Edgardo A. Hernández, ${ }^{1}$ Gustavo A. Ferreyra, ${ }^{2}$ Lucas A.M. Ruberto ${ }^{1,3}$ \& Walter P. Mac Cormack ${ }^{2}$ \\ 1 Cátedra de Biotecnología, Facultad de Farmacia y Bioquímica, Universidad de Buenos Aires, A. Junín $9566^{\circ}$ piso, Código Postal C1113AAD, \\ Buenos Aires, Argentina \\ 2 Instituto Antártico Argentino, Cerrito 1248, Código Postal C1010AAZ, Buenos Aires, Argentina \\ 3 Consejo Nacional de Investigaciones Científicas y Técnicas, Rivadavia 1917, Código Postal C1033AAJ, Buenos Aires, Argentina
}

\author{
Keywords \\ Antarctica; marine bacteria; \\ psychrotolerants; UV radiation; \\ water column.

\section{Correspondence} \\ Walter Mac Cormack, Instituto Antártico \\ Argentino, Cerrito 1248, Código Postal \\ C1010AAZ, Buenos Aires, Argentina. \\ E-mail:wmac@ffyb.uba.ar
}

doi:10.1111/j.1751-8369.2009.00111.x

\begin{abstract}
The effect of UVR on the viability of the culturable bacterial community fraction ( $\mathrm{CBC}$ ), and two of their isolated components (Arthrobacter-UVvi and Bizionia-UVps), was studied in the top few metres of the water column at Potter Cove, King George Island, Antarctica. Quartz flasks containing CBC from surface waters were exposed to solar radiation at depths of 0,1 and $3 \mathrm{~m}$. Similar experiments using UVps and UVvi isolates were performed. In some experiments interferential filters were used to discriminate photosynthetic active radiation (PAR), UV-A and UV-B. CBC from depths of 0,10 and $30 \mathrm{~m}$ were also exposed to surface solar radiation. The deleterious effect of UVR was observed at the surface and at a depth of $1 \mathrm{~m}$, but not at a depth of $3 \mathrm{~m}$. Studies with interferential filters showed low bacterial viability values at depths of 0 and $1 \mathrm{~m}$ under both UVR treatments. However, under low radiation doses the effect attributed to UV-B was higher than that caused by UV-A. The surface CBC was more resistant to UVR compared with $\mathrm{CBC}$ from a depth of $30 \mathrm{~m}$. The results showed that $\mathrm{CBC}$ inhabiting waters above the pycnocline (located at a depth of 5-10 m) are more efficiently adapted to UVR than are those from below the pycnocline. The impact of UVR on the marine bacterioplankton studied was only detected in the first metre of the stratified water column of Potter Cove, which has high levels of suspended particulate matter. These results support the evidence for a significant UVR-attenuating effect in the water column of this coastal Antarctic water.
\end{abstract}

The water column represents a selective filter for the different UVR bands (280-400 nm), with UV-B (280$315 \mathrm{~nm}$ ) being more strongly attenuated than UV-A (315-400 nm) and photosynthetic active radiation (PAR; 400-700 nm) (Smith \& Baker 1979).

The Antarctic waters of the open ocean are typically oligotrophic, and are characterized by low concentrations of suspended particulate matter, as well as low levels of phytoplankton biomass and productivity (Hapter et al. 1983; Schloss et al. 1997). Under such conditions, the biological effects of UVR can be detected down to ca. $30 \mathrm{~m}$ in depth (Karentz \& Lutze 1990). However, in coastal Antarctic environments, the UVR transmitted through the water column can greatly fluctuate as a result of significant changes in the optical properties across different seasons. Potter Cove is a shallow inlet $(50-100 \mathrm{~m}$ in depth) receiving a high input of suspended particles from freshwater run-off, mainly during the spring-summer period (Klöser et al. 1994; Varela 1998; Schloss et al. 2002). The combination of a strong shallow pycnocline and high levels of suspended particles result in a low penetration of light through the water column, but there is also a high residence time of particles and microorganisms within the first ca. $5 \mathrm{~m}$ (Schloss \& Ferreyra 2002). Consequently, the surface layer of Potter Cove represents an interesting natural model to investigate the response of cells suspended in the water column to solar radiation.

It is well known that the Antarctic region has been exposed, in the last few decades, to increased levels of UV-B as a result of the reduction in the thickness of the stratospheric ozone layer (Staehelin et al. 2001). Several papers have shown that UV-B causes direct damage to 
marine microorganisms, including bacteria (Vincent $\delta$ Neale 2000). Bacteria seem to be more sensitive to UV-B than other planktonic microorganisms because of their small size (Jeffrey et al. 1996; Boelen et al. 2001). On the other hand, UV-A is not significantly filtered by the ozone layer, and some authors have reported that such wavelengths, rather than UV-B, are the main factor causing deleterious effects on marine microorganisms (Booth et al. 2001; Hernández et al. 2004). As many of the previous studies investigated the effects of exposing bacterioplankton to direct sunlight using interferential filters, or exposing them to artificial radiation from lamps, the in situ effects of UV-A and UV-B on marine microorganisms suspended at different depths in the water column have been poorly analysed.

Although it is known that the culturable bacterial communities (CBC) only represent a minor fraction of the entire bacterioplankton community (Sherr et al. 2001), knowledge of the responses from this fraction, as well as from isolated strains, is a useful tool for inferring the response of the marine bacterial community as a whole. For example, Fernandez Zenoff et al. (2006) used the CBC to evaluate the effect of UV-B on the bacterial flora from high-altitude wetland waters.

Therefore, the main goals of this work were: (1) to study the effects of solar radiation on the $\mathrm{CBC}$ from surface waters in the first $3 \mathrm{~m}$ of the water column, and compare it with those observed for two previously described Antarctic marine bacterial isolates; (2) to discriminate the effects of PAR, UV-A and UV-B on the same biological models; (3) to analyse changes in the viability of $\mathrm{CBC}$ obtained from three different depths $(0,10$ and $30 \mathrm{~m}$ ) after exposure to surface UV irradiance.

\section{Materials and methods}

\section{Study area and bacterial strains}

Field experiments were carried out at Potter Cove, King George Island (Isla 25 de Mayo), 62 ${ }^{\circ} 14^{\prime}$ S, 58 $40^{\prime} \mathrm{W}$, South Shetland Islands, Antarctica. Laboratory experiments were conducted in the Argentinean-German Dallmann Laboratory at Jubany Station (Argentina), located on the shore of the Potter Peninsula.

The bacterial strains used in this study, Arthrobacter UVvi (a pleomorphic, yellow-pigmented Gram-positive strain) and Bizionia UVps (a Gram-negative orangepigmented rod strain), were isolated and characterized previously (Hernández et al. 2004). Partial $16 S$ rDNA sequences of Bizionia UVps and Arthrobacter UVvi are deposited in GenBank under the accession numbers AY220353 and AY220354, respectively.

\section{Light measurements}

The incident solar radiation was measured continuously using a multichannel UV spectroradiometer developed at the Alfred Wegener Institute for Polar and Marine Research. This instrument is based on a Bentham DM 150 double monochromator (Bentham Instruments, Reading, Berkshire, UK), with a multichannel detector system. Underwater light measurements were made using an underwater spherical quantum sensor (LI 193 SA), and an underwater spectroradiometer (also developed by the Alfred Wegener Institute), similar to the ground-based instrument, mounted in a waterproof housing. The UV-B sensor measures irradiance of 280-323 nm. The underwater instruments were deployed from a small Zodiac boat (for a more detailed description, see Richter et al. 2008).

\section{Experimental designs}

Experiments conducted in the water column during the Antarctic summers 2003/04 and 2004/05 were made using a set of quartz bottles containing $50 \mathrm{ml}$ of either seawater or mixed bacterial suspension. Quartz bottles were submerged into the water column and maintained at three fixed depths: surface, $1 \mathrm{~m}$ and $3 \mathrm{~m}$.

In experiment 1, a surface water sample previously filtered through a $2-\mu \mathrm{m}$ pore cellulose filter was placed into the quartz bottles. The aim of this experiment was to analyse the response of the $\mathrm{CBC}$ from the surface when exposed to solar radiation at different levels of the water column. In experiments 2-5, quartz flasks contained suspensions of the isolated bacteria. These suspensions were prepared from liquid cultures of each isolate under exponential growth phase, and contained approximately $10^{7}$ colony-forming units per $\mathrm{ml}\left(\mathrm{CFU} \mathrm{m} \mathrm{m}^{-1}\right)$. Aliquots of these cultures were diluted 1 : 100 in sterile seawater, and were then placed into the quartz bottles for each experiment. In experiments 4 and 5, interferential filters (Mylar and Plexiglas) were used to cover the flasks, thereby determining four different treatments (by triplicates): (1) dark control (i.e. black filter); (2) PAR, covered with a 420-nm cut-off filter (Plexiglas UF3; Arkema, Phildelphia, PA, USA); (3) UV-A (PAR + UV-A), covered with a 320-nm cut-off filter (Mylar; Dupont, Wilmington, DE, USA); (4) UV-B (PAR + UV-A + UV-B) (quartz bottles without filters). In addition, two experiments (6 and 7) were carried out on land. Quartz bottles were filled with $50 \mathrm{ml}$ of previously filtered (with a $2-\mu \mathrm{m}$ pore filter) seawater obtained from depths of 0,10 and $30 \mathrm{~m}$. Flasks were placed in an incubation chamber and exposed to solar radiation on the shore of Potter Cove. The chamber was immersed in a continuous water circulation 
bath to minimize thermal oscillations in the flasks (the average temperature during the assay was $4.7 \pm 1^{\circ} \mathrm{C}$ ). In this case, interferential quartz filters (Schott, Mainz, Germany) were used to cover the top of the flasks, and the same four treatments (by triplicates), described above, were used (i.e., DARK, PAR, UV-A and UV-B).

In all experiments, samples from the different treatments were taken at 2 and $6 \mathrm{~h}$. Serial dilutions of the samples were plated $(0.1 \mathrm{ml})$ on marine agar (Difco 2216; BD, Franklin Lakes, NJ, USA) and incubated in the dark for 30 days at $4{ }^{\circ} \mathrm{C}$. Counts were performed on plates presenting 30-300 colonies, and the results were expressed as $\mathrm{CFU} \mathrm{ml} \mathrm{m}^{-1}$. Hereafter, we express the decreases in bacterial counts as a "loss of viability". Although it is known that only a fraction of any bacterial community is able to grow on a nutrient medium, we used the term bacterial viability in reference to the culturability of the studied bacterial community and isolated strains.

The UV-B dose received by the bacterial suspension for each experiment is shown in Table 1.

\section{Statistical analysis}

The bacterial counts data were analysed by repeated measures ANOVAs, Tukey's multiple comparison tests and Dunnet contrasts.

Table 1 Doses of UV-B radiation measured at the indicated sampling times during the different experiments performed at Potter Cove, King George Island, Antarctica.

\begin{tabular}{|c|c|c|}
\hline \multicolumn{3}{|c|}{ UV-B dose $\left(\mathrm{kJ} \mathrm{m}^{-2}\right)$} \\
\hline Exp. 1 & $2 \mathrm{~h}$ & $6 \mathrm{~h}$ \\
\hline $0 \mathrm{~m}$ & 3.20 & 4.60 \\
\hline $1 \mathrm{~m}$ & 0.61 & 0.80 \\
\hline $3 \mathrm{~m}$ & 0.017 & 0.028 \\
\hline \multicolumn{3}{|l|}{ Exp. 2} \\
\hline $0 \mathrm{~m}$ & 8.37 & 20.11 \\
\hline $1 \mathrm{~m}$ & 2.09 & 5.02 \\
\hline $3 \mathrm{~m}$ & 0.008 & 0.002 \\
\hline \multicolumn{3}{|l|}{ Exp. 3} \\
\hline $0 \mathrm{~m}$ & 1.20 & 4.33 \\
\hline $1 \mathrm{~m}$ & 0.33 & 1.20 \\
\hline $3 \mathrm{~m}$ & 0.025 & 0.093 \\
\hline \multicolumn{3}{|l|}{ Exp. 4} \\
\hline $0 \mathrm{~m}$ & - & 9.50 \\
\hline $1 \mathrm{~m}$ & - & 1.90 \\
\hline $3 \mathrm{~m}$ & - & 0.04 \\
\hline \multicolumn{3}{|l|}{ Exp. 5} \\
\hline $0 \mathrm{~m}$ & - & 4.80 \\
\hline $1 \mathrm{~m}$ & - & 1.21 \\
\hline $3 \mathrm{~m}$ & - & 0.076 \\
\hline \multicolumn{3}{|l|}{ Exp. 6} \\
\hline & 3.80 & 7.28 \\
\hline \multicolumn{3}{|l|}{ Exp. 7} \\
\hline & 2.35 & 3.50 \\
\hline
\end{tabular}

\section{Results}

\section{Effect of UVR on the bacteria of the water column}

The water column proved to exert an attenuating effect on UVR, thereby reducing the loss of viability of the CBC from Potter Cove. Figure 1 shows changes in the viability of the surface $\mathrm{CBC}$ after exposure to solar radiation (at depths of 0,1 and $3 \mathrm{~m}$ ), incubated in flasks without interferential filters. At the surface, significant deleterious effects $(P<0.05)$ were observed after $2 \mathrm{~h}$ of exposure (UV-B dose $3.2 \mathrm{~kJ} \mathrm{~m}^{-2}$ ): i.e., the $\mathrm{CBC}$ changed from $1.15 \times 10^{4}$ at the start of the time period to $2.70 \times 10^{3} \mathrm{CFU} \mathrm{m} \mathrm{m}^{-1}$ after exposure. This effect was $4.5-$ fold higher after $6 \mathrm{~h}$ of exposure, when the UV-B dose reached $4.6 \mathrm{~kJ} \mathrm{~m}^{-2}$. The $\mathrm{CBC}$ was also significantly affected $(P<0.01)$ at a depth of $1 \mathrm{~m}$, but to a lesser extent. In this case, the counts were $7.50 \times 10^{3}$ and $2.75 \times 10^{3} \mathrm{CFU} \mathrm{m} \mathrm{m}^{-1}$ at 2 and $6 \mathrm{~h}$, respectively. On the other hand, no significant negative effects were observed at a depth of $3 \mathrm{~m}$.

When the two marine isolates were exposed to the same experimental conditions, we observed that after $2 \mathrm{~h}$ of exposure at a depth of $0 \mathrm{~m}$ (with a UV-B dose of $8.4 \mathrm{~kJ} \mathrm{~m}^{-2}$ ) both strains showed a significant decrease in viability, compared with the dark treatment $(P<0.05)$. The viable count of strain UVvi was reduced by $50 \%$,

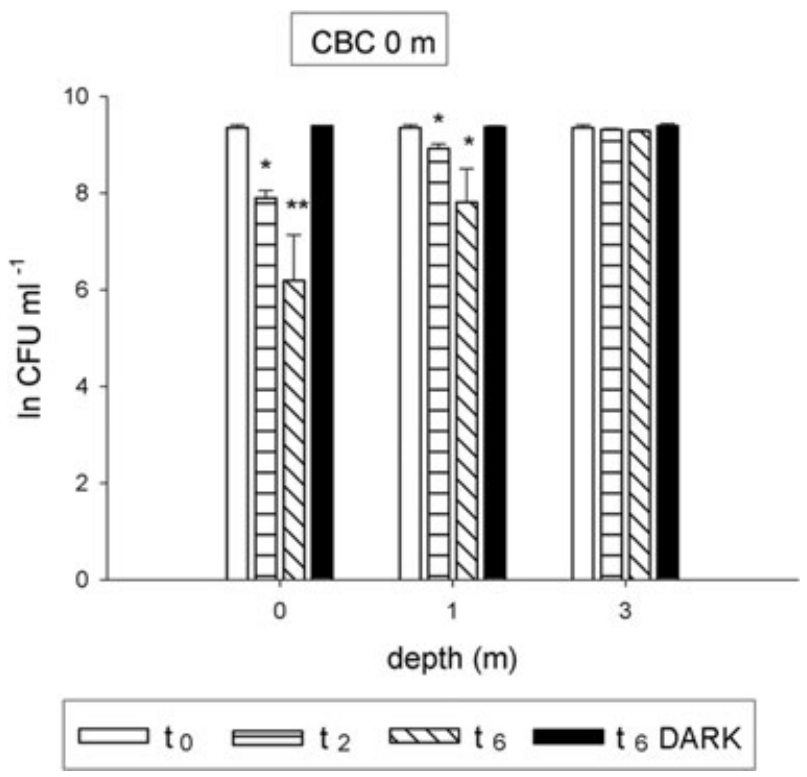

Fig. 1 Effect of solar radiation on the viability of the surface culturable bacterial community (CBC) placed on the water column at depths of 0,1 and $3 \mathrm{~m}$ (experiment 1). Viability was evaluated at the beginning of the experiments $\left(t_{0}\right)$, at $2 \mathrm{~h}\left(t_{2}\right)$ and at $6 \mathrm{~h}\left(t_{6}\right) .{ }^{*} P<0.05,{ }^{*} P P<0.01$; irradiance treatments compared with dark controls at the same depths. Error bars indicate the standard deviation of triplicates. 
whereas the viable count of strain UVps was reduced by $90 \%$ (Fig. 2). At the end of this experiment (6 h) the UV-B dose at the surface was $20.1 \mathrm{~kJ} \mathrm{~m}^{-2}$, and both strains showed viability values of lower than $1 \%$. At a depth of $1 \mathrm{~m}$, the UV-B dose reached $2.1 \mathrm{~kJ} \mathrm{~m}^{-2}$ after $2 \mathrm{~h}$, and the viability was $45 \%$ for both strains. However, after $6 \mathrm{~h}$, the viability values were reduced to $25 \%$ and $1 \%$ for UVvi and Uvps, respectively. Finally, at a depth of $3 \mathrm{~m}$ the exposure to UV-B was very low $\left(8.4 \times 10^{-3} \mathrm{~kJ} \mathrm{~m}^{-2}\right)$. In
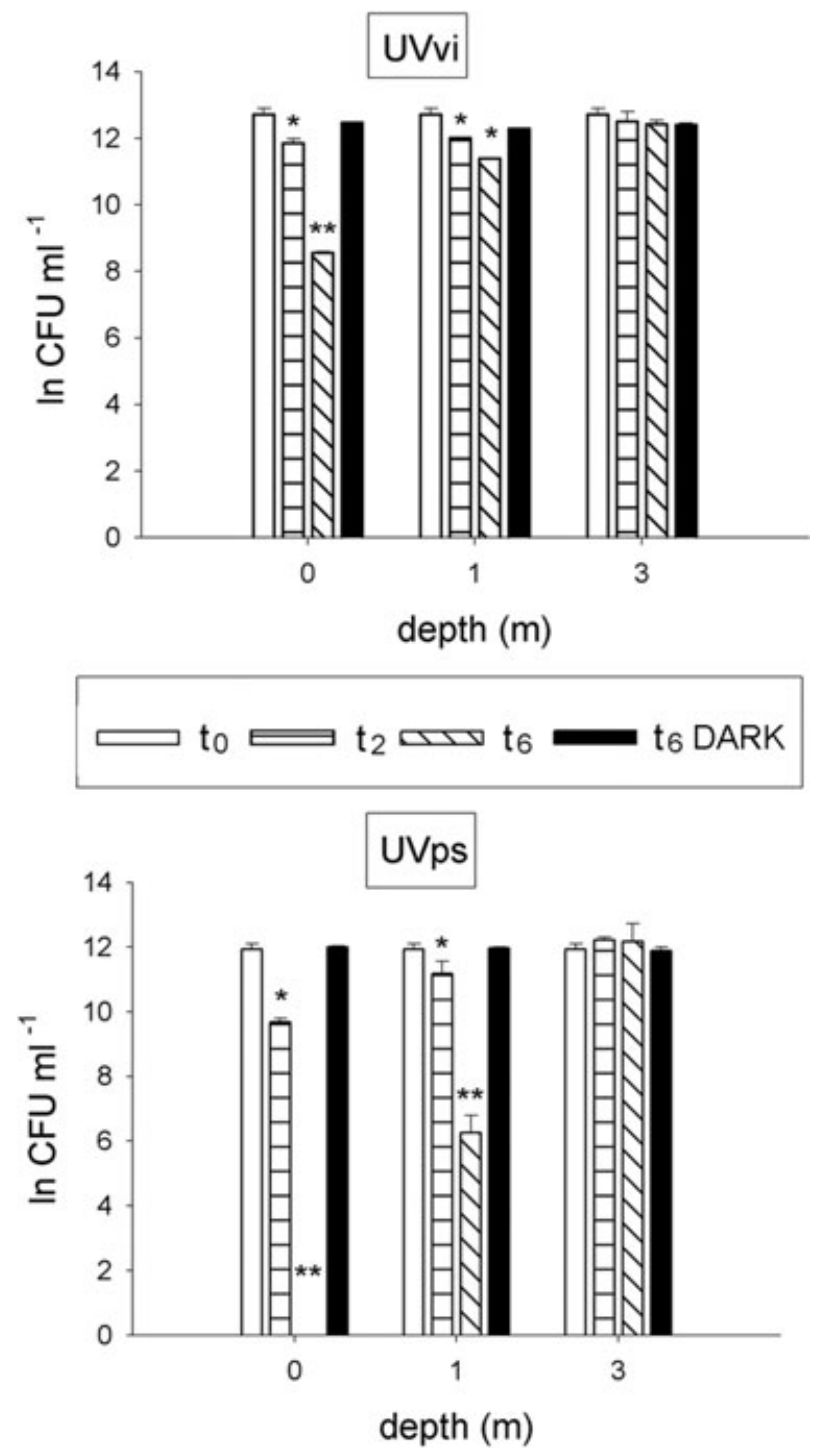

Fig. 2 Effect of solar radiation on the viability of strains UVps (Bizionia) and UVvi (Arthrobacter) placed on the water column at depths of 0,1 and $3 \mathrm{~m}$, when the total UV-B dose at the surface was $20.11 \mathrm{~kJ} \mathrm{~m}^{-2}$ (experiment 2). The viability was evaluated at the beginning of the experiments $\left(t_{0}\right)$, at $2 \mathrm{~h}\left(t_{2}\right)$ and at $6 \mathrm{~h}\left(t_{6}\right) .{ }^{*} P<0.05,{ }^{*} P<<0.01$; irradiance treatments compared with dark controls at the same depths. Error bars indicate the standard deviation of triplicates. this case strains did not show significant differences in viability between irradiated and dark conditions. When the same experimental set-up was with a lower solar irradiance, the deleterious effects were strongly attenuated (Fig. 3). This observation was reflected by the viability values observed at the end of the assay (after $6 \mathrm{~h}$ ), when the UV-B dose at the surface was $4.3 \mathrm{~kJ} \mathrm{~m}^{-2}$. Under such conditions, UVvi showed a significantly lower viability value $(10 \%, P<0.05)$ only at the surface. In
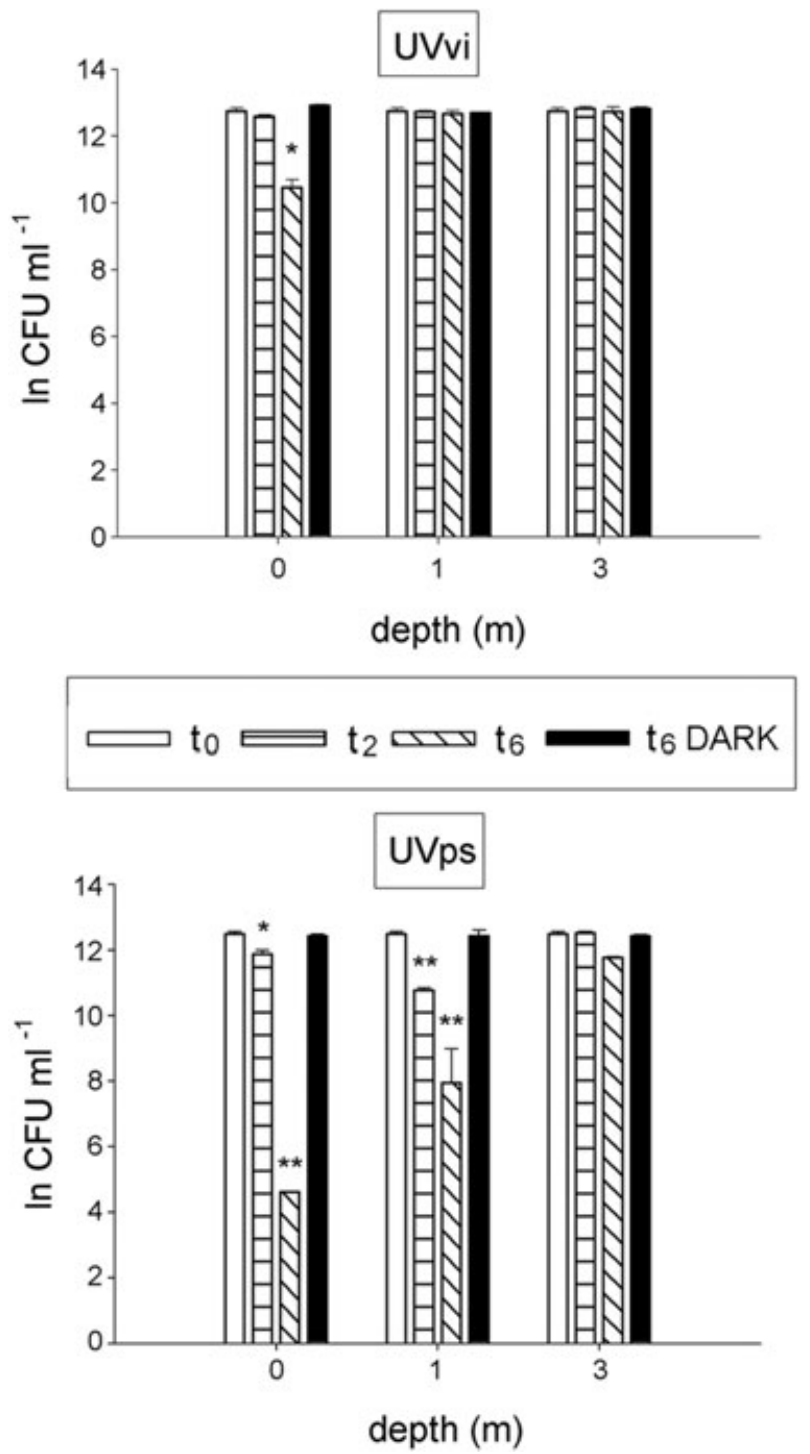

Fig. 3 Effect of solar radiation on the viability of strains UVps (Bizionia) and UVvi (Arthrobacter) placed on the water column at depths of 0,1 and $3 \mathrm{~m}$, when the total UV-B dose at the surface was $4.33 \mathrm{~kJ} \mathrm{~m}^{-2}$ (experiment 3). The viability was evaluated at the beginning of the experiments $\left(t_{0}\right)$, at $2 \mathrm{~h}\left(t_{2}\right)$ and at $6 \mathrm{~h}\left(t_{6}\right) .{ }^{*} P<0.05,{ }^{*} \mathrm{P}<0.01$; irradiance treatments compared with dark controls at the same depths. Error bars indicate the standard deviation of triplicates. 
contrast, the UVps strain showed significant decreases in viability $(P<0.01)$ not only at the surface but also at a depth of $1 \mathrm{~m}$ (to 1 and $10 \%$, respectively). No significant effects were observed on both strains at a depth of $3 \mathrm{~m}$ $(P>0.05)$.

\section{Differential effects of UV-A and UV-B on the isolated strains}

The use of interferential filters confirmed that PAR radiation had no effect on the studied strains at any of the irradiance regimes or depths tested in this work, and that all negative effects observed on the strains were related to UVR (data not shown). Consequently, the effects of UV-A on both strains were expressed in terms of the fractional loss of viability (FLV\%), determined with the following equation:

$$
\left(1-\left[\mathrm{CFU}_{\mathrm{UV}-\mathrm{A}} / \mathrm{CFU}_{\mathrm{PAR}}\right]\right) \times 100,
$$

where $\mathrm{CFU}_{\mathrm{UV}-\mathrm{A}}$ represents the CFU in the UV-A treatment, and $\mathrm{CFU}_{\mathrm{PAR}}$ represents the CFU in the PAR treatment. In the same way, the FLV\% resulting from exposure to UV-B was calculated as:

$$
\left(1-\left[\mathrm{CFU}_{\mathrm{UV}-\mathrm{B}} / \mathrm{CFU}_{\mathrm{UV}-\mathrm{A}}\right]\right) \times 100,
$$

where $\mathrm{CFU}_{\mathrm{UV}-\mathrm{B}}$ represents the CFU in the UV-B treatment.

In one of the assays (Fig. 4), the surface UV-B dose was $9.5 \mathrm{~kJ} \mathrm{~m}^{-2}$ after $6 \mathrm{~h}$ of exposure. In this case, a high FLV\% for the strain UVvi resulted from exposure to UV-A at both the surface $(70 \%)$ and at a depth of $1 \mathrm{~m}(52 \%$; $P<0.05)$. The presence of UV-B did not add any significant effect at these depths. This fact is reflected by an FLV\% close to 0 for the UV-B treatment. At a depth of $3 \mathrm{~m}$, strain UVvi was not affected by exposure to UV-A, whereas exposure to UV-B produced only a weak negative effect (13\% FLV). Under the same conditions, the other strain (UVps) was also deeply affected by UV-A at depths of both 0 and $1 \mathrm{~m}$ (Fig. 4), showing higher FLV\% values than those observed for UVvi (99.9 and 94\%, respectively). The magnitude of the responses to UV-B was similar, with FLV values of 90.4 and $99.0 \%$ at depths of 0 and $1 \mathrm{~m}$, respectively. At a depth of $3 \mathrm{~m}$, UV-A had no effect on the viability of UVps, but UV-B caused significant deleterious effects (46.5\% FLV).

Under a UV-B dose of approximately half that registered during the experiment described above $\left(4.8 \mathrm{~kJ} \mathrm{~m}^{-2}\right.$ at 6 h; Fig. 5), only UV-A affected the viability of the two strains at the surface, with the effect on strain UVvi $(22 \%$ FLV) being less than that found for UVps (31\% FLV). Neither UVvi nor UVps strains evidenced negative effects at depths of 1 and $3 \mathrm{~m}$ upon exposure to UV-A. In contrast, the exposure of strain UVvi to UV-B resulted in significant inactivation $(P<0.05)$ at depths of 0 and $1 \mathrm{~m}$, which was evidenced by the FLV\% values (65 and 19\%,
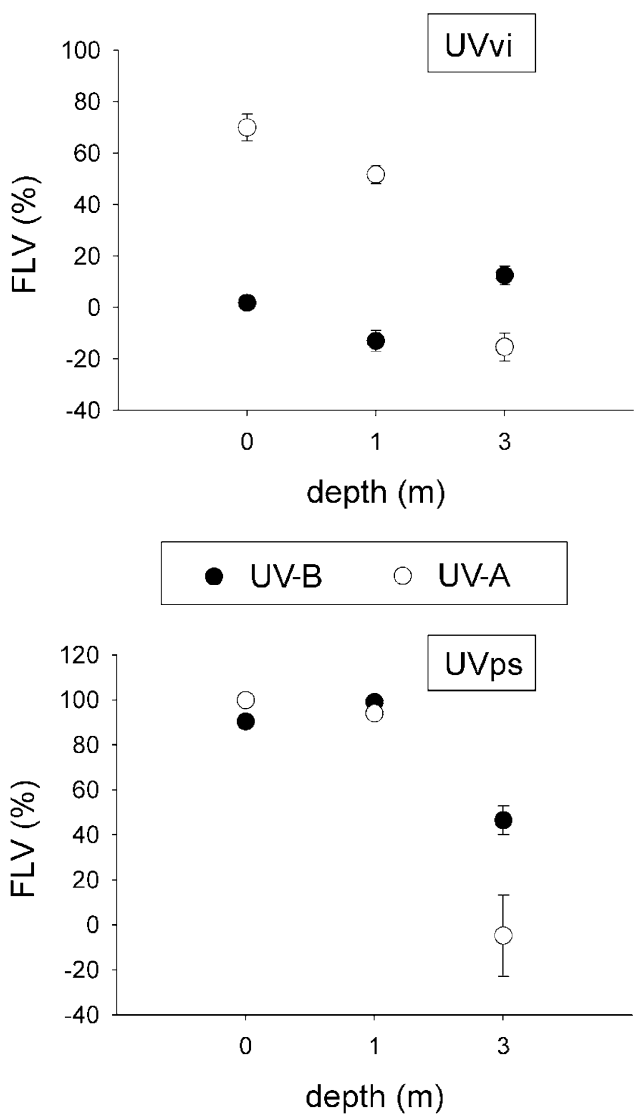

Fig. 4 The fractional loss of viability (FLV\%) observed for strains UVps (Bizionia) and UVvi (Arthrobacter) placed on the water column at depths of 0,1 and $3 \mathrm{~m}$, when the total UV-B dose at the surface was $9.5 \mathrm{~kJ} \mathrm{~m}^{-2}$ (experiment 4). See text for details about the calculation of FLV. Error bars indicate the standard deviation of triplicates.

respectively). UVps was also affected at the same depths (97\% FLV at $0 \mathrm{~m}$ and $67 \%$ FLV at $1 \mathrm{~m}$ ), showing a higher sensitivity to this UVR band than UVvi. Finally, although the FLV\% values were positive ( 18 and $21 \%$ for UVvi and Uvps, respectively) upon exposure to UV-B at a depth of $3 \mathrm{~m}$, these values were not significantly different from those caused by UV-A.

\section{Effect of UVR on CBC obtained from different depths in the water column}

When the CBC obtained from depths of 0,10 and $30 \mathrm{~m}$ were exposed to solar radiation reaching the surface of the Earth, we observed different responses depending of the depth from which the CBC were obtained, but also depending on the radiation dose. As shown in Table 1, during the first $2 \mathrm{~h}$ of experiment 6 the bacterial cells received one-half of the total dose of the full experiment, even though $2 \mathrm{~h}$ represents only a third of the total expo- 
sure period. This fact could in part explain the high loss of viability observed in this initial period of exposure (Table 2). After $2 \mathrm{~h}$ (with a UV-B dose of $3.8 \mathrm{~kJ} \mathrm{~m}^{-2}$ ) the surface CBC was only affected after exposure to UV-B, whereas the CBC from depths of 10 and $30 \mathrm{~m}$ were significantly $(P<0.05)$ affected by exposure to both UV-A and UV-B. However, whereas the $\mathrm{CBC}$ from a depth of $10 \mathrm{~m}$ was more affected $(P<0.05)$ by exposure to UV-B
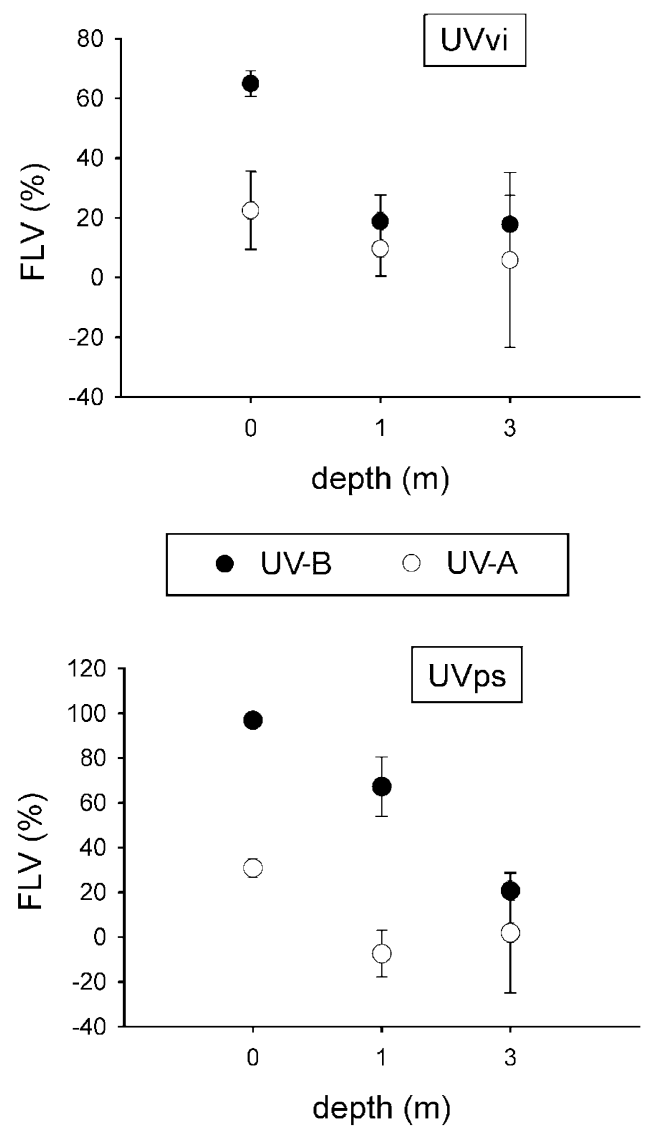

Fig. 5 The fractional loss of viability (FLV\%) observed for strains UVps (Bizionia) and UVvi (Arthrobacter) placed on the water column at depths of 0,1 and $3 \mathrm{~m}$, when the total UV-B dose at the surface was $4.8 \mathrm{~kJ} \mathrm{~m}^{-2}$ (experiment 5). See text for details about the calculation of FLV. Error bars indicate the standard deviation of triplicates. than to UV-A, the CBC from a depth of $30 \mathrm{~m}$ showed similar losses of viability under both UV treatments. It is important to note that the negative effect of UV-B on the surface CBC was significantly lower $(P<0.05)$ than on $\mathrm{CBC}$ from depths of 10 and $30 \mathrm{~m}$, which showed no differences between them.

When the UV-B dose was 50\% lower than that registered for experiment 6 , as was the case in experiment 7 , $\mathrm{CBC}$ from depths of 0 and $10 \mathrm{~m}$ responded in a similar way, showing no significant differences when compared with the dark controls. Under these conditions, CBC from a depth of $30 \mathrm{~m}$ showed a significant loss of viability $(P<0.05)$, with the effect of exposure to UV-B being significantly greater $(P<0.05)$ compared with UV-A. Significant differences between PAR and dark treatments were not observed during both experiments (data not shown).

\section{Discussion}

It is well known that concentrations of suspended particulate matter (SPM) and dissolved organic matter (DOM) in the water column strongly scatter and absorb UVR, potentially reducing the damaging effects on cells. Such UVR decrease is mostly evidenced in coastal waters, and is more marked in the UV-B range than in the UV-A range (Tedetti \& Sempéré 2006). Studies performed in tropical coastal waters reported that UV-B values were attenuated by more than $90 \%$ in the first metre of the water column (Wilhelm et al. 2002). A similar situation was observed in the present studies at Potter Cove, where UV-B was attenuated by ca. $99 \%$ at a depth of $3 \mathrm{~m}$. Most of the light absorption in the water column of Potter Cove can be related to the high SPM load originating from terrestrial freshwater inputs during spring and summer (Klöser et al. 1994). A recent study by Richter et al. (2008) determined that for some days during summer there is severely reduced UVR penetration, with UVR being completely absorbed at a depth of $2 \mathrm{~m}$.

On the other hand, Gustavson et al. (2000) have reported that the UV-B-induced photodegradation of DOM may enhance carbon availability, and hence bacte-

Table 2 Percentage of viability observed for culturable bacterial communities (CBC) from depths of 0,10 and 30 m, exposed to surface photosynthetic active radiation (PAR) + UV-A, and PAR + UV-A + UV-B solar radiation (experiments 6 and 7, respectively).

\begin{tabular}{|c|c|c|c|c|c|c|c|}
\hline & & 0-m CBC & & 10-m CBC & & 30-m CBC & \\
\hline & & $2 \mathrm{~h}$ & $6 \mathrm{~h}$ & $2 \mathrm{~h}$ & $6 \mathrm{~h}$ & $2 \mathrm{~h}$ & $6 \mathrm{~h}$ \\
\hline Exp. 6 & UV-A & $88.45 \pm 23.55$ & $103.8 \pm 16.26$ & $66.66 \pm 4.19 *$ & $57.68 \pm 7.61 *$ & $37.57 \pm 18.85^{\star \star}$ & $37.04 \pm 18.73^{\star \star}$ \\
\hline & $U V-A+U V-B$ & $62.82 \pm 5.44$ & $71.79 \pm 10.88$ & $46.66 \pm 9.42^{\star}$ & $35.38 \pm 6.53^{\star *}$ & $40.60 \pm 5.99 * *$ & $29.24 \pm 1.65^{\star \star}$ \\
\hline Exp. 7 & UV-A & $95.28 \pm 12.54$ & $98.25 \pm 7.43$ & $86.00 \pm 6.36$ & $91.15 \pm 11.71$ & $32.50 \pm 3.53^{\star *}$ & $32.99 \pm 6.46^{* *}$ \\
\hline & $U V-A+U V-B$ & $77.92 \pm 19.47$ & $93.57 \pm 3.51$ & $89.75 \pm 8.83$ & $87.84 \pm 17.18$ & $26.25 \pm 1.76 * \star$ & $20.81 \pm 5.74 * \star$ \\
\hline
\end{tabular}

${ }^{\star} P<0.05,{ }^{\star *} P<0.01$; irradiance treatments compared with dark controls at the same depths. 
rial activity, potentially compensating for the growth losses caused by damage to cellular DNA. This fact could lead to a compensation of the negative effects of UV-B, and to the absence of a net change in bacterial activity. However, this is not the case for this study, where the negative effect of UV-B on the Antarctic bacteria analysed seems to overcome any possible positive effect resulting from the increase in nutrients available for bacterial growth. This hypothesis can be supported by the low DOM concentrations $(<50 \mu \mathrm{M}$ C) reported for Potter Cove (Abele et al. 1999; Ferreyra et al. 2008).

Despite the limitations of the culture methods to study bacterial communities, which were mentioned in the introduction, a number of recent studies have used the culturable fraction to analyse functional characteristics as well as the responses to environmental changes (Frette et al. 2004). For example, Fernandez Zenoff et al. (2006) reported a significant decrease in cell numbers after exposure to UVR, using the CBC to infer the effect of solar radiation. In addition, when the goal of research is to analyse changes in the viability of cells, or in the components of the community, occurring within short time scales (i.e., a few hours), as was the case in our study, the evaluation of the culturable fraction of the bacterial community and their loss of viability could be a more realistic approach than the qualitative and quantitative evaluation of the components by molecular methods. In these cases, independently of their physiological state, or if the bacterial cells are dead or alive, DNA of all the original components will remain in the suspension during the whole period studied, leading to the detection of bacterial groups that are not really active at the time of sampling.

In our study, the CBC from the surface showed no adaptation to the solar radiation reaching the surface waters. This fact is suggested by the loss of viability observed after only $2 \mathrm{~h}$ of solar exposure. This deleterious effect on surface CBC was also observed to a minor extent at a depth of $1 \mathrm{~m}$, but was not significant at a depth of $3 \mathrm{~m}$, where the water column seemed to completely attenuate the effect of solar radiation. The results obtained with the isolated strains suggest that each component of the CBC has a different response to radiation, and that some components are more sensitive and others more resistant than the $\mathrm{CBC}$ analysed as a whole. Not all of the CBC components exhibit total resistance to radiation, as would be expected from a CBC that was fully adapted to such conditions. This result differs to some extent from those obtained by Helbling et al. (1995), who found that two bacterial isolates were more sensitive to solar radiation than the $\mathrm{CBC}$ from the same site. They also reported that a Gram-positive isolate (Bacillus sp.) was more sensitive than a Gram-negative Acinetobacter sp. In previous works we have observed significant differ- ences in the UVR sensibility of the strains, with the Gramnegative UVps being more affected that the Gram-positive UVvi (Hernández et al. 2006). This higher UVR resistance of Gram-positive compared with Gram-negative bacteria has also been reported by other authors (Fernandez Zenoff et al. 2006). A differential response of the bacterioplankton components to UVR was also reported by other authors (Joux et al. 1999; Arrieta et al. 2000).

The deleterious effect of UV-A on marine bacteria has previously been observed in the Antarctic (Booth et al. 2001; Hernández et al. 2006), and in other aquatic environments (Sommaruga et al. 1997). In an experiment performed in the marine Antarctic water column, Helbling et al. (1995) concluded that the impact of UV-A on two bacteria isolates and $\mathrm{CBC}$ was consistently greater than the impact of UV-B. Although our results agree with the aforementioned finding under high irradiances, we did not observe such an effect for UV-A when the solar radiation was low, as in our experiment 5. Also, differences between strains were evident under high irradiances: only UVvi was affected by exposure to UV-A, with the additional effect of exposure to UV-B being negligible; exposure to UV-B caused a significant additional mortality for UVps, compared with the damage caused by exposure to UV-A. Under moderate or low radiation levels, UV-B not only had a significant negative effect, but this negative effect was greater than that of UV-A. This effect was similar for both of the strains studied. A comparable situation seems to occur at a depth of $3 \mathrm{~m}$ under high levels of surface irradiance, where UV-B also had the greatest effect. Taking into account that cloudy days and moderate to low irradiance are by far the most frequent conditions in Antarctica (Hoyer et al. 2001), this differential effect of UV-B could be the main reason for the damage to bacterioplankton, particularly during spring and early summer, when the ozone hole is largest.

Although the water column is not a static system, and the vertical mixing could homogenize the microbial components from different depths, our results suggest a different situation. As observed in experiment 6, the CBC from the surface showed a higher resistance level to UVR than the CBC from depths of 10 and $30 \mathrm{~m}$. When the UV-B dose was only a half of that registered during experiment 6, only the $\mathrm{CBC}$ from a depth of $30 \mathrm{~m}$ was affected, thereby confirming the lesser degree of adaptation of this CBC to the surface UVR.

Two main features dominate the hydrological structure of the water column in Potter Cove during spring and summer. On one hand the water column develops a strong pycnocline at a depth of ca. 5-10 m, which to some extent isolates the surface waters from deeper ones. This pycnocline results from an intense freshwater input from the land. On the other hand, the strong winds (wind 
speed $>4 \mathrm{~m} \mathrm{~s}^{-1}$ ) that characterize this area periodically cause the breakdown of this structure, homogenizing the water column (Schloss \& Ferreyra 2002; Schloss et al. 2002). Our experiments performed with the natural CBC from depths of 0,10 and $30 \mathrm{~m}$ reflect the adaptation of the community to the first scenario, i.e., a well-stratified water column. The different response shown by the surface bacterial community compared with CBC from a depth of $30 \mathrm{~m}$ reinforce the assumption that the pycnocline could be acting as a threshold, partially separating the microbial communities present below and above the pycnocline. However, static incubations of the natural community from surface waters at depths of 0 and $1 \mathrm{~m}$ resulted in a significant loss of viability, suggesting that such adaptation may not be enough to cope with the damaging effects of UVR.

These results suggest that in sites such as Potter Cove, where high levels of SPM greatly reduce the penetration of UVR, vertical mixing is one of the main factors in reducing the loss of viability caused by surface UVR. However, further studies simulating in situ vertical mixing are necessary to feed models to assess the real effects of these radiations on the bacterioplankton community of Antarctic coastal waters.

\section{Acknowledgements}

We thank Oscar Gonzalez and Leonardo Cantoni for technical assistance, and the Alfred Wegener Institute for providing the UV-B data and laboratory facilities. This research was supported in part by the Instituto Antártico Argentino PICTA 10 grant.

\section{References}

Abele D., Ferreyra G.A. \& Schloss I.R. 1999. $\mathrm{H}_{2} \mathrm{O}_{2}$ accumulation from photochemical production and atmospheric wet deposition in Antarctic off-shore waters of Potter Cove, King George Island, South Shetland Islands. Antarctic Science 11, 131-139.

Arrieta J.M., Weinbauer M.G. \& Herndl G.J. 2000. Interspecific variability in sensitivity to UV radiation and subsequent recovery in selected isolates of marine bacteria. Applied and Environmental Microbiology 66, 1468-1473.

Boelen P., Vernet M.J.W. \& Buma A.G.J. 2001. Accumulation and removal of UVBR-induced DNA damage in marine tropical plankton subjected to mixed and simulated non-mixed conditions. Aquatic Microbial Ecology 24, 265-274.

Booth M.G., Hutchinson L.A., Brumsted M., Aas P., Coffin R.B., Downer Jr R.C., Kelley C.A., Maille Lyons M., Pakulski J.D., Holder Sandvik S.L., Jeffrey W.H. \& Miller R.V. 2001. Quantification of recA gene expression as an indicator of repair potential in marine bacterioplankton communities of Antarctica. Aquatic Microbial Ecology 24, 51-59.

Ferreyra G.A., Schloss I.R., Mercuri G., Ferreyra L. \& Richter K. 2008. The potential ecological significance of dissolved and particulate matter in the water column of Potter Cove, King George Island (Isla 25 de Mayo), South Shetland Islands. In C. Wiencke et al. (eds.): Synopsis of research performed at the Dallmann Laboratory and Jubany Station (Antarctica). Reports on Polar Research 571, 47-58.

Fernandez Zenoff V., Heredia J., Ferrero M., Siñeriz F. \& Farias M.A. 2006. Diverse UV-B resistance of culturable bacterial community from high-altitude wetland water. Current Microbiology 52, 359-362.

Frette L., Johnsen K., Jørgensen N., Nybroe O. \& Kroer N. 2004. Functional characteristics of culturable bacterioplankton from marine and estuarine environments. International Microbiology 7, 219-227.

Gustavson K., Garde K., Wängberg S.A. \& Selmer J.S. 2000. Influence of UV-B radiation on bacterial activity in coastal waters. Journal of Plankton Research 22, 1501-1511.

Hapter R., Wozniak B. \& Dobrowolski K. 1983. Primary production in Ezcurra Inlet during the Antarctic summer of 1977/78. Oceanologia 15, 175-184.

Helbling E.W., Marguet F.R., Villafañe V.E. \& Holm-Hansen O. 1995. Bacterioplankton viability in Antarctic waters as affected by solar ultraviolet radiation. Marine Ecology Progress Series 126, 293-298.

Hernández E.A., Ferreyra G.A. \& Mac Cormack W.P. 2004. Effect of solar radiation and the subsequent dark periods on two newly isolated Antarctic marine bacteria. Polar Research 23, 67-77.

Hernández E.A., Ferreyra G.A. \& Mac Cormack W.P. 2006. Response of two Antarctic marine bacteria to different solar UV radiation wavelengths. Antarctic Science 18, 205-212.

Hoyer K., Karsten U., Sawall T. \& Wiencke C. 2001. Photoprotective substances in Antarctic macroalgae and their variation with respect to depth distribution, different tissues and developmental stages. Marine Ecology Progress Series 211, 117-129.

Jeffrey W. H., Pledger R.J., Aas P., Hager S., Coffin R.B., Von Haven R. \& Mitchell D.L. 1996. Diel and depth profiles of DNA photodamage in bacterioplankton exposed to ambient solar ultraviolet radiation. Marine Ecology Progress Series 137, 283-291.

Joux F., Jeffrey W.H, Lebaron P. \& Mitchell D.L. 1999. Marine bacterial isolates display diverse responses to UV-B radiation. Applied Environmental Microbiology 65, 3820-3827.

Karentz D. \& Lutze L.H. 1990. Evaluation of biologically harmful ultraviolet radiation in Antarctica with a biological dosimeter designed for aquatic environments. Limnology Oceanography 35, 549-561.

Klöser H., Ferreyra G., Schloss I.R., Mercuri G., Laturnus F. \& Curtosi A. 1994. A hydrography of Potter Cove, a small fiord-like inlet on King Geoge Island, South Shetland. Estuarine Coastal Shelf Science 38, 523-537. 
Richter A., Wuttke S. \& Zacher K. 2008. Two years of in situ UV measurements at Dallmann Laboratory/Jubany Station. In C. Wiencke et al. (eds.): Synopsis of research performed at the Dallmann Laboratory and Jubany Station (Antarctica). Reports on Polar Research 571, 12-19.

Schloss I.R. \& Ferreyra G.A., 2002. Primary production, light and vertical mixing in Potter Cove, a shallow Bay in the maritime Antarctic. Polar Biology 25, 41-48.

Schloss I.R., Ferreyra G.A. \& Ruiz-Pino D. 2002. Phytoplankton biomass in Antarctic shelf zones: a conceptual model based on Potter Cove, King George Island. Journal of Marine Systems 36, 129-143.

Schloss I.R., Klöser H., Ferreyra G.A., Mercuri G. \& Pinola E. 1997. Factors governing phytoplankton and particulate matter variation in Potter Cove, King George Island, Antartica. In B. Battaglia et al. (eds.): Antarctic communities. Pp. 135-141. Cambridge: Cambridge University Press.

Sherr B., Sherr E. \& del Giorgio P. 2001. Enumeration of total and highly active bacteria. In J.H. Paul (ed.): Methods in microbiology. Vol. 30. Marine microbiology. Pp. 129-159. London: Academic Press.

Smith R.C. \& Baker K.S. 1979. Penetration of UV-B and biologically effective dose-rates in natural waters. Photochemistry and Photobiology 29, 311-323.
Sommaruga R., Oberleiter A., Herndl G.J. \& Psenner R. 1997. Inhibitory effect of solar radiation on thymidine and leucine incorporation by freshwater and marine bacterioplankton. Applied Environmental Microbiology 63, 4178-4184.

Staehelin J., Harris N.R.P., Appenzeller C. \& Ebenhard J. 2001. Ozone trends: a review. Reviews of Geophysics 39, 231-290.

Tedetti M. \& Sempéré R. 2006. Penetration of ultraviolet radiation in the marine environment. A review. Photochemistry and Photobiology 82, 389-397.

Varela L. 1998. Hydrology of Matias and Potter creeks. Reports on Polar Research 299, 33-39.

Vincent W.F. \& Neale P.J. 2000. Mechanisms of UV damage to aquatic organisms. In S.J. de Mora et al. (eds.): The effects of UV radiation in the marine environment. Pp. 149-156. Cambridge: Cambridge University Press.

Wilhelm S.W., Jeffrey W.H., Suttle C.A. \& Mitchell D.L. 2002. Estimation of biologically damaging UV levels in marine surface waters with DNA and viral dosimeters. Photochemistry and Photobiology 76, 268-273. 